\title{
SERUM COPPER WITH CORONARY ARTERY DISEASE IN MALE AND ITS RELATION WITH LIPID PROFILE
}

\author{
SIFAT JUBAIRA, FORHADUL HAQUE MOLLAH, TAHRIM MEHDI, M IQBALARSLAN
}

Department of Biochemistry, Bangabandhu Sheikh Mujib Medical University, Dhaka, Bangladesh

\begin{abstract}
The study was designed to explore serum copper as a risk factor for coronary artery disease (CAD). In this case-control study 30 healthy controls and 60 diagnosed cases of acute myocardial infarction (AMI) were enrolled. Serum copper concentration and serum lipid profile were measured in all study subjects. Serum copper level was significantly higher in AMI as compared to controls. The concentrations of serum TC, TG, LDL-C level were found to be significantly higher in cases as compared to controls. The concentration serum HDL-C was found to be significantly lower in cases as compared to controls. CAD leads to raised serum copper level and it has positive correlation with $T C, T G$ and $L D L-C$ but negative correlation with HDL-C in males.
\end{abstract}

Keywords: Coronary artery disease, serum copper, acute myocardial infarction, total cholesterol, triglyceride, low density lipoprotein cholesterol.

(Bangladesh J Physiol Pharmacol 2008; 24(1\&2) : 7-9)

\section{INTRODUCTION}

The term coronary artery disease (CAD) covers a group of clinical syndrome that include angina, myocardial infarction and chronic ischemic heart disease which is stratified by different investigation such as electrocardiography (ECG), echocardiography (Echo), exercise tolerance test (ETT), coronary angiography (CAG) and biochemical markers ${ }^{1}$. The morbidity and mortality from CAD is alarming ${ }^{2}$. In England and Wales, $30 \%$ women die as a result $C A D^{3}$. The death rate from $\mathrm{CAD}$ in the United Kingdom is among the highest in the world 4 . According to one survey, prevalence rate of CAD in Bangladesh is 3.3 per thousand and the incidence is increasing at a rate of $0.5 \%$ per year ${ }^{5}$. Various works had been done on CAD and its risk factors. An exhaustive list of 246 coronary risk factors which included every possible coronary risk factor was proposed ${ }^{6}$.

Excess serum copper as a risk factor for CAD is a relatively newer concept. Copper is an essential trace element that is a constituent of certain metalloenzymes and protein. It is required for the haemoglobin synthesis by helping iron absorption and is a constituent of cytochrome-oxidase, tyrosinase, monoamine-oxidase, ascorbic acid oxidase, uricase and galactose oxidase ${ }^{7}$. So this transition metal is an essential micronutrient for enzyme that catalyzes oxidation reduction reaction ${ }^{8}$. Oxidation is now thought to play an important role in the pathogenesis of CAD through oxidation of LDL-C and free radical formation and it has been suggested that the oxidation of LDL-C increases atherogenecity ${ }^{9}$.

Address for correspondence: Dr. Sifat Jubaira, Department of Biochemistry, Bangabandhu Sheikh Mujib Medical University, Dhaka
An imbalance in copper metabolism has been reported to predispose to CAD in western population, but there is little data for other racial group. Serum copper concentration appears to be variable according to age and sex and female has higher copper concentration as compare to male 10 .

Therefore, the present work has been designed to evaluate the association of serum copper with CAD in male and also to find out the relation among serum copper with other common risk factors of CAD like raised TC, TG, LDL-C \& decreased HDL-C.

\section{MATERIALS AND METHODS}

A case-control study was conducted in the Department of Biochemistry, BSMMU, in cooperation with the department of Cardiology of BSMMU and Coronary Care Unit (CCU) of National Institute of Cardiovascular Disease (NICVD), Dhaka from July 2007 to June 2008. A total of 90 male subjects were included in the study. Out of them 30 were healthy controls and 60 were diagnosed cases of AMI based on history, characteristic ECG changes and evidence of elevated enzyme level. Ethical clearance was taken from the Institutional Ethical Committee of BSMMU and informed written consent was taken from all study subjects preserving their rights, privileges \& freedom. Serum copper concentration was estimated by Atomic Absorption Spectrophotometer and serum TC, Tg, LDL-C \& HDL-C was measured enzymatically by CHOD- PAP by micro flow cell photometer.

\section{Statistical analysis}

All data were recorded systematically in a preformed data sheet. Statistical analysis was performed by using 
SPSS for windows version 12.0. Correlation coefficient test and unpaired t test were done as tests of significance. $95 \%$ confidence limit $(p<0.05)$ was taken as level of significance.

\section{RESULTSAND DISCUSSION}

In this case control study attempt was made to evaluate the role of copper in CAD. Serum copper concentration was compared between 60 diagnosed cases of CAD and 30 matched controls. Total cholesterol, triglyceride, low density lipoprotein cholesterol \& high density lipoprotein cholesterol were measured and compared between two groups. Correlation test was also done in cases between serum copper with lipid profile.

Table-I

Serum copper concentration in both cases and controls

\begin{tabular}{lcccc}
\hline Parameter & $\begin{array}{c}\text { Case } \\
(\mathrm{n}=60)\end{array}$ & $\begin{array}{c}\text { Control } \\
(\mathrm{n}=30)\end{array}$ & $\begin{array}{c}\mathrm{t}- \\
\text { value }\end{array}$ & $\begin{array}{c}\mathrm{p}- \\
\text { value }\end{array}$ \\
\hline Serum copper & $185.90 \pm$ & 166.67 & & \\
$($ ugm/dl) & 23.75 & \pm 36.88 & 2.60 & $<0.5$ \\
Mean \pm SD & & & & \\
\hline
\end{tabular}

Table II

Comparison of serum lipid profile between case \& control

\begin{tabular}{|c|c|c|c|c|}
\hline Parameter & $\begin{array}{l}\text { Case } \\
(n=60)\end{array}$ & $\begin{array}{l}\text { Control } \\
(n=30)\end{array}$ & $\begin{array}{c}\text { t- } \\
\text { value }\end{array}$ & $\begin{array}{c}\mathrm{p}- \\
\text { value }\end{array}$ \\
\hline TC (mg/dl) & $227.12 \pm$ & $203.23 \pm$ & 4.229 & $<0.01$ \\
\hline mean $\pm S D$ & 34.69 & 18.85 & & \\
\hline $\mathrm{TG}(\mathrm{mg} / \mathrm{dl})$ & $171.52 \pm$ & $152.27 \pm$ & 5.208 & $<0.001$ \\
\hline mean $\pm S D$ & 20.86 & 13.87 & & \\
\hline LDL-C (mg/dl) & 161.11士 & $132.53 \pm$ & 5.401 & $<0.001$ \\
\hline mean $\pm S D$ & 33.04 & 17.14 & & \\
\hline HDL-C (mg/dl) & $31.97 \pm$ & $39.87 \pm$ & -7.410 & $<0.001$ \\
\hline mean $\pm S D$ & 5.71 & 4.21 & & \\
\hline
\end{tabular}

Table III

Correlation of serum copper with lipid profile in cases

\begin{tabular}{cccc}
\hline \multicolumn{2}{c}{ Variable } & "r" value & "P" value \\
Copper & TC & 0.17 & $>0.05$ \\
\hline & TG & 0.63 & $>0.05$ \\
LDL-C & 0.19 & $>0.05$ \\
& HDL-C & -0.13 & $>0.05$ \\
\hline
\end{tabular}

Serum copper concentration in cases was found to be significantly $(p<0.5)$ higher than that of controls (Table I) and this finding is similar to that of the studies done by Salonen et al $(1991)^{11}$ and Jukka et al. $(1991)^{12 .}$
Raised TC, TG, LDL-C \& lower HDL-C concentration was found in both the study group. The concentration of TC, TG, LDL-C was significantly higher \& the concentration of HDL-C was significantly lower in cases than that of control (Table II). These findings are partially similar to Jukka et al. (1991) ${ }^{12}$, who found that serum copper concentration correlated positively with LDL-C. These conflicting findings regarding different components of lipid profile may be due to different dietary habit, life style, and ethnicity of our study subjects than that of the studies done abroad.

Present study showed significantly higher serum copper concentration and TC, TG, LDL-C \& lower concentration of HDL-C in cases as compared to controls and also revealed positive correlation between serum copper with total cholesterol, triglyceride, and low density lipoprotein cholesterol.

From the present work it may be suggested that high serum copper concentration with other major risk factors like elevated TC, TGL, LDL-C \& decreased HDL$\mathrm{C}$ may be responsible for coronary artery disease in male. Estimation of serum progesterone, testosterone and serum corticosteroid level might be responsible for increased serum copper. Therefore, further prospective study involving a larger sample size after controlling the confounders may be carried out to draw a definite conclusion.

\section{REFERENCES}

1. Julian DG, Cowan JC, Mclenachan JM. Disease of the coronary arteries-causes, pathology and prevention. In: Cardiology, $7^{\text {th }}$ edn, WB Saunders Company Itd, 1998; 92105.

2. Nicholas M, Willett WC, Rimm EB. Dietary iron intake and risk of coronary disease among men. Circulation 1994; 89: 969-977.

3. Marmot M, Tekawa IS, Hurley LB. Iron stores are not associated with acute myocardial infarction. Circulation 1996; 89: 2915.

4. Boon NA, Fox KA, Bloomfield P. Disease of the cardiovascular system. In: Haslet C, Chilvers ER, Hunter JA, Boon NA, (eds), Davidson's principles and practice of medicine, $18^{\text {th }}$ edn, Churchill Livingstone 1999; 191-302.

5. Malik A. The primary prevention of myocardial infarction. BMRC Bulletin 1987; 23: 110-114.

6. Hopkins K, Williams R. Coronary risk in British population. Int J Epidemiol 1981; 23: 375

7. Burch RE, Hahn HKJ, Sullivan JF. Newer aspect of the role of zinc, magnesium and copper in human nutrition. Clin Chem Journal 1989; 21: 501. 
8. Linder MC, Hazegh-Azam M. Copper biochemistry and molecular biology. Am J Clin Nutr 1996; 63: 797s-811s.

9. Steinberg D, Parthasarathy S, Carew TE, et al. Beyond cholesterol: modification of low density lipoprotein that increase its atherogenecity. N Engl J Med 1989; 320: 91524.

10. Milne DB. Copper intake and assesment of copper status. Am J Clin Nutr 1998; 67: 1041-5.
11. Salonen JT, Salonen R, Korpela H, Suntioinen S, Tuomilehto J. Serum copper and the risk of acute myocardial infarction: a prospective population study in men in Eastern Finland'. Am J Epidemiol 1991; 134: 268-276.

12. Jukka T, Heikki, Korpela, Sirpa, Suntionen and Jakko, Tuimelehto. Serum copper and the risk of acute myocardial infarction: A prospective population study in men in eastern Finland. Am J Epidemiol 1991; 134: 268-76. 